\section{Disianneng}

DESASSOSSEGO 13 | JUN/2015 | ISSN 2175-3180

DOI: http://dx.doi.org/10.11606/issn.2175-3180.v7i13p147-147

\title{
Pequeno retrato do tempo
}

Clarissa Macedo ${ }^{1}$

Comovido, o seio levanta

ao sinal do primeiro cio.

Distante, aquela senhora sonha

a primavera cardíaca da rua;

a moça que compreende trapos

cogita a possibilidade de um

poema

e a tarde cede ao crepúsculo

sem novidade, sem ruído.

De cabelo sujo, o rapaz

engorda e se pesa na farmácia,

se pensa no peso do mundo -

os vitrais pincelam mais uma

multidão.

As cápsulas daquele antídoto

estão vazias

e as estrelas seguem calmas

céu abaixo,

desenhando uma nova solidão. ${ }^{1}$ Doutoranda em Literatura e Cultura (UFBA). Autora de O trem vermelho que partiu das cinzas e Na pata do cavalo
há sete abismos (2014). 